\title{
Penerapan Model Pembelajaran Berbasis Proyek dalam Materi Statistika Kelas VIII SEKOlah Menengah Pertama
}

\author{
Iyam Maryati ${ }^{1,2}$ \\ 1Program Studi Matematika, Institut Pendidikan Indonesia \\ Jl. Pahlawan No. 32 Sukagalih, Garut, Jawa Barat, Indonesia \\ maryati_iyam@yahoo.co.id \\ ${ }^{2}$ Mahasiswa Doktoral, Universitas Pendidikan Indonesia \\ Jl. Setiabudhi No.229, Isola, Sukasari, Bandung, Jawa Barat, Indonesia
}

Artikel diterima: 10 Mei 2018, direvisi: 24 September 2018, diterbitkan: 30 September 2018

\begin{abstract}
Abstrak
Artikel ini merupakan studi literatur yang betujuan untuk mendeskripsikan Model Pembelajaran Berbasis Proyek yang diterapkan dalam materi statistika pada siswa kelas VIII Sekolah Menengah Pertama. Dalam artikel ini juga menyajikan Rencana Pelaksanaan Pembelajaran (RPP) sebagai alternatif dalam pelaksanaan pembelajaran. Berdasarkan telaah literatur dari penelitian yang relevan diperoleh kemampuan lierasi dan penalaran statistis baik siswa SMP maupun SMA masih dalam kategori rendah. Hal ini terjadi karena sangat dipengaruhi oleh model pembelajaran yang diterapkan. Dalam model pembelajaran berbasis proyek ini guru diberikan kesempatan untuk melakukan pembelajaran yang melibatkan kerja proyek. Hasil akhir dari kerja proyek tersebut dapat berupa laporan dan presestasi. Adapun penilaian tugas proyek diawali dari proses perencanaan, pelaksanaan, dan akhir tugas proyek. Oleh karena itu model pembelajaran berbasis proyek dapat dijadikan sebagai salah satu alternatif dalam pembelajaran.

Kata Kunci: Pembelajaran Berbasis Proyek, Statistika, Rencana Pelaksanaan Pembelajaran
\end{abstract}

\begin{abstract}
Conducting Project Based Learning in Statistics of $8^{\text {th }}$ Grade Junior High School Students)

This article is a literature study which aims to describe the Project-Based Learning Model that is applied in statistical material for students of grade VIII of junior high school. In this article also presents a Learning Implementation Plan (RPP) as an alternative in the implementation of learning. Based on the review of literature from relevant research, it was found that the ability and statistical statistics of junior and senior high schools were still in the low category. This happens because very much the text by the learning model is applied. In the learning, project, development, development and development models. The end result of the work can be in the form of reports and presentations. Arrange the work done from the project planning, implementation and final project. Therefore, project-based learning models can be used as an alternative in learning.

Keyword: Project-Based Learnin, Statistics, Learning Implementation Plan
\end{abstract}




\section{Pendahuluan}

Dalam membangun sebuah tatanan masyarakat pada sebuah bangsa terletak pada kualitas sumber daya manusia. Untuk membangun kualitas sumber daya manusia yang baik itu tidak akan terwujud kecuali dengan pendidikan. Sehingga pendidikan memiliki peranan yang sangat penting dan strategis dalam membangun masyarakat yang berpengetahuan. Pada abad ke-21 ini persaingan dalam berbagai bidang kehidupan semakin kompetitif. Oleh karena itu pendidikan yang diterapkan harus membentuk keterampilan belajar yang dapat berkompetisi dalam mengatasi masalahyang harus ditempuh yaitu dengan peningkatan mutu pendidikan. (The Partnership for 21st Century Skills, "21st century skills, education \& competitiveness," 2008).

Dalam Permendikbud Nomor 65 tahun 2013 tentang Standar Proses dinyatakan bahwa karakteristik pembelajaran pada setiap satuan pendidikan terkait erat dengan Standar Kompetensi Lulusan dan Standar Isi. Standar kompetensi lulusan memberikan kerangka konseptual tentang sasaran pembelajaran yang harus dicapai. Standar isi memberikan kerangka konseptual tentang kegiatan belajar dan pembelajaran yang diturunkan dari tingkat kompetensi dan ruang lingkup materi. Sasaran pembelajaran mencakup pengembangan ranah sikap, pengetahuan, masalah yang dihadapi Salah satu cara

dan keterampilan yang dielaborasi untuk setiap satuan pendidikan.

Demikian pula dalam Permendikbud Nomor 66 tahun 2013 tentang standar penilaian bahwa seorang pendidik untuk menilai kompetensi keterampilan melalui penilaian kinerja yaitu penilaian yang menuntut siswa mendemonstrasikan suatu kemampuan tertentu dengan menggunakan tes praktik, proyek, dan penilaian portofolio.

Selain itu, dalam Permendikbud Nomor 66 tahun 2013 ini bahwa seorang pendidik untuk menilai kompetensi keterampilan melalaui penilaian kinerja yaitu penilaian yang menuntut siswa mendemonstrasikan suatu kompetensi tertentu dengan menggunakan tes praktik, proyek dan penilaian portofolio. Untuk penilaian proyek yang dilakukan oleh seorang pendidik, masih menurut Standar penilaian adalah dilakukan setiap akhir bab atau tema pelajaran.

Berkaitan dengan materi statistika pada kelas VIII ini, penulis telah melakukan analisis kemampuan literasi statistis pada 35 orang siswa Madrasah Tsanawiyah tahun ajaran 2016/2017 di kabupaten Garut dengan hasil penelitian menunjukkan sebesar 35\% siswa mampu dalam membaca data statistika yang diberikan dalam bentuk tabel, diagram, dan grafik, sebesar 32\% kemampuan dalam memahami konsep, sebesar 30\% kemampuan dalam mengkomunikasikan pengolahan data, dan sebesar $28 \%$ kemampuan dalam mempresentasikan hasil pengolahan data. Selain menganalisis kemampuan literasi statistis, penulis juga telah menganalisis miskonsepsi siswa 
terhadap penalaran statistika pada 32 orang siswa Madrasah Tsanawiyah yang lainnya di kabupaten Garut dengan hasil "The mean value of misconception test was 49,7 and standard deviation was 10,6 whereas the mean value of statistical reasoning skill test was 51,8 and standard deviation was 8,5. If the minimal value is 65 to state the standard achievement of a course competence, students' mean value is lower than the standard competence".

Kemampuan literasi statistis juga diteliti oleh Hafiyusholeh (2017) menunjukkan bahwa siswa SMA menunjukkan bahwa siswa membaca data dimulai dari memperhatikan judul grafik kemudian menggali informasi yang tersaji dalam grafik tersebut. Dalam menafsirkan dan menyimpulkan data, siswa memperhatikan pola umum dan fluktuasi data dan menggunakan tren data umum untuk memprediksi data.

Sedangkan kemampuan literasi matematik terhadap mahasiswa calon guru matematiika diteliti oleh Prabawati, N.M. (2018) menunjukkan dari 3 mahasiswa yang dijadikan sebagai subjek penelitian, yaitu M1 (mahasiswa berkemampuan tinggi), M2 (mahasiswa berkemampuan sedang), M3 (mahasiswa berkemampuan rendah). Berdasarkan analisis yang sudah dilakukan M1 berada pada level 4 kemampuan literasi matematik, M2 berada pada level 3 kemampuan literasi matematik, dan M3 berada pada level 2 kemampuan literasi matematik.

Dari hasil penelitian yang relevan tersebut, penulis memiliki anggapan bahwa kemampuan siswa dalam literasi statistis, penalaran statistis, dan literasi matematis sangat dipengaruhi oleh model pembelajaran yang diterapkan oleh guru. Oleh karena itu berdasarkan teori-teori pembelajaran dan didukung dengan penelitian yang relevan, penulis memiliki asumsi bahwa model pembelajaran berbasis proyek dapat dijadikan alternatif model pembelajaran.

\section{PEMBAHASAN}

\section{A. Model Pembelajaran Berbasis Proyek}

Dalam rasional perubahan kurikulum sebelumnya (KTSP/Kurikulum 2006) ke kurikulum 2013 disebutkan bahwa perkembangan pengetahuan dan pedagogi dalam hal ini neurologi, psikologi, observation based (discovery) learning dan collaborative learning adalah salah satu alasan pentingnya perubahan kurikulum. Hal ini tentu berimplikasi pada modelmodel pembelajaran yang digunakan dalam kegiatan mengajar di sekolah. Salah satu model pembelajaran yang dianjurkan untuk digunakan adalah model pembelajaran berbasis proyek (project based learning). Hal ini tentunya bukan tanpa alasan, karena mengingat terdapat karakteristik unggul dari model pembelajaran ini yang mampu mengakomodasi alasan tersebut.

Model pembelajaran berbasis proyek (Project Based Learning) merupakan salah satu model pembelajaran yang dapat digunakan oleh guru sehingga secara 
otomatis guru berarti juga menggunakan pendekatan saintifik (scientific approach) dalam pembelajarannya. Pendekatan saintifik adalah pendekatan pembelajaran di mana siswa memperoleh pengetahuan berdasarkan cara kerja ilmiah. Melalui pendekatan saintifik ini siswa akan diajak meniti jembatan emas sehingga ia tidak hanya mendapatkan ilmu pengetahuan (knowledge) semata tetapi juga akan mendapatkan keterampilan dan sikapsikap yang dibutuhkan dalam kehidupannya kelak. Saat belajar menggunakan model pembelajaran berbasis proyek ini, siswa dapat berlatih menalar secara induktif (inductive reasoning). Sebagai salah satu model pembelajaran dalam pendekatan saintifik, project based learning (model pembelajaran berbasis proyek) sangat sesuai dengan Permendikbud Nomor $81 \mathrm{~A}$ Tahun 2013 Lampiran IV mengenai proses pembelajaran yang harus memuat $5 \mathrm{M}$, yaitu: (1) mengamati; (2) menanya; (3) mengumpulkan informasi; (4) mengasosiasi; dan (5) mengkomunikasikan (Kemdikbud, 2013).

Dalam model pembelajaran berbasis proyek ini, siswa melakukan pembelajaran aktif. Mereka benar-benar akan dibuat aktif baik secara hands on (melalui kegiatan-kegiatan fisik), maupun secara minds on (melalui kegiatan-kegiatan berpikir/secara mental). Karena itulah, ruh dari pelaksanaaan model pembelajaran berbasis proyek ini sesuai sekali dengan amanat Kurikulum 2013. Siswa, melalui pembelajaran aktif akan melakukan 470 aktifitas 5M (mengamati, menanya, mengumpulkan informasi, mengasosiasi, dan mengkomunikasikan).

Di dalam pelaksanaannya, model pembelajaran berbasis proyek memiliki langkah-langkah (sintaks) yang menjadi ciri khasnya dan membedakannya dari model pembelajaran lain seperti model pembelajaran penemuan (discovery learning model) dan model pembelajaran berdasarkan masalah (problem based learning model). Adapun langkah-langkah itu adalah; (1) menentukan pertanyaan dasar; (2) membuat desain proyek; (3) menyusun penjadwalan; (4) memonitor kemajuan proyek; (5) penilaian hasil; (6) evaluasi pengalaman.

Model pembelajaran berbasis proyek selalu dimulai dengan menemukan apa sebenarnya pertanyaan mendasar, yang nantinya akan menjadi dasar untuk memberikan tugas proyek bagi siswa (melakukan aktivitas). Tentu saja topik yang dipakai harus pula berhubungan dengan dunia nyata. Selanjutnya dengan dibantu guru, kelompok-kelompok siswa akan merancang aktivitas yang akan dilakukan pada proyek mereka masingmasing. Semakin besar keterlibatan dan ide-ide siswa (kelompok siswa) yang digunakan dalam proyek itu, akan semakin besar pula rasa memiliki mereka terhadap proyek tersebut. Selanjutnya, guru dan siswa menentukan batasan waktu yang diberikan dalam penyelesaian tugas (aktivitas) proyek mereka.

Dalam berjalannya waktu, siswa melaksanakan seluruh aktivitas mulai dari Mosharafa: Jumal Pendidikan Matematika Volume 7, Nomor 3, September 2018 Copyright $\odot 2018$ Mosharafa: Jurnal Pendidikan Matematika 
persiapan pelaksanaan proyek mereka hingga melaporkannya sementara guru memonitor dan memantau perkembangan proyek kelompok-kelompok siswa dan memberikan pembimbingan yang dibutuhkan. Pada tahap berikutnya, setelah siswa melaporkan hasil proyek yang mereka lakukan, guru menilai pencapaian yang siswa peroleh baik dari segi pengetahuan (knowledge terkait konsep yang relevan dengan topik), hingga keterampilan dan sikap yang mengiringinya. Terakhir, guru kemudian memberikan kesempatan kepada siswa untuk merefleksi semua kegiatan (aktivitas) dalam pembelajaran berbasis proyek yang telah mereka lakukan agar di lain kesempatan pembelajaran dan aktivitas penyelesaian proyek menjadi lebih baik lagi.

\section{Langkah-langkah}

pelaksanaan pembelajaran berbasis proyek:

1. Penentuan Pertanyaan Mendasar (Start With the Essential Question).

Pembelajaran dimulai dengan pertanyaan esensial yaitu pertanyaan yang dapat memberi penugasan kepada siswa dalam melakukan suatu aktivitas. Topik penugasan sesuai dengan dunia nyata yang relevan untuk siswa. dan dimulai dengan sebuah investigasi mendalam.

2. Mendesain Perencanaan Proyek (Design a Plan for the Project)

Perencanaan dilakukan secara kolaboratif antara guru dan siswa. Dengan demikian siswa diharapkan akan merasa "memiliki" atas proyek tersebut. Perencanaan berisi tentang aturan main, pemilihan aktivitas yang dapat mendukung dalam menjawab pertanyaan esensial, dengan cara mengintegrasikan berbagai subjek yang mungkin, serta mengetahui alat dan bahan yang dapat diakses untuk membantu penyelesaian proyek.

3. Menyusun Jadwal (Create a Schedule)

Guru dan siswa secara kolaboratif menyusun jadwal aktivitas dalam menyelesaikan proyek. Aktivitas pada tahap ini antara lain: (1) membuat timeline(alokasi waktu) untuk menyelesaikan proyek, (2) membuat deadline (batas waktu akhir) penyelesaian proyek, (3) membawa peserta didik agar merencanakan cara yang baru, (4) membimbing peserta didik ketika mereka membuat cara yang tidak berhubungan dengan proyek, dan (5) meminta peserta didik untuk membuat penjelasan (alasan) tentang pemilihan

4. Memonitor siswa dan kemajuan proyek (Monitor the Students and the Progress of the Project)

Guru bertanggungjawab untuk melakukan monitor terhadap aktivitas siswa selama menyelesaikan proyek. Monitoring dilakukan dengan cara menfasilitasi siswa pada setiap proses. Dengan kata lain guru berperan menjadi mentor bagi aktivitas siswa. Agar mempermudah proses monitoring, dibuat sebuah rubrik yang dapat merekam keseluruhan aktivitas yang penting.

5. Menguji Hasil (Assess the Outcome)

Penilaian dilakukan untuk membantu guru dalam mengukur ketercapaian standar, berperan dalam mengevaluasi 
kemajuan masing- masing siswa, memberi umpan balik tentang tingkat pemahaman yang sudah dicapai siswa, membantu guru dalam menyusun strategi pembelajaran berikutnya.

6. Mengevaluasi Pengalaman (Evaluate the Experience)

Pada akhir pembelajaran, guru dan siswa melakukan refleksi terhadap aktivitas dan hasil proyek yang sudah dijalankan. Proses refleksi dilakukan baik secara individu maupun kelompok.

Penilaian tugas proyek Penilaian proyek merupakan kegiatan penilaian terhadap suatu tugas yang harus diselesaikan dalam periode atau waktu tertentu. Tugas tersebut berupa suatu investigasi atau penyelidikan sejak dari perencanaan, pengumpulan data, pengorganisasian, pengolahan dan penyajian data. Penilaian proyek dapat digunakan untuk mengetahui pemahaman, kemampuan mengaplikasikan, kemampuan penyelidikan dan kemampuan siswa memberikan informasi tentang sesuatu yang menjadi penyelidikannya pada materi tertentu secara jelas. Widyantini (2014) menjelaskan bahwa penilaian proyek ada 3 (tiga) hal yang perlu dipertimbangkan yaitu: (a) Kemampuan pengelolaan yaitu kemampuan siswa dalam memilih topik apabila belum ditentukan oleh guru, mencari informasi dan mengelola waktu pengumpulan data serta penulisan laporan, (b) Relevansi yaitu kesesuaian dengan mata pelajaran dengan mempertimbangkan tahap pengetahuan, pemahaman dan keterampilan dalam pembelajaran), (c) Keaslian yaitu proyek yang dilakukan siswa harus merupakan hasil karyanya, dengan mempertimbangkan kontribusi guru berupa petunjuk dan dukungan terhadap proyek siswa.

Sedangkan Baker (2011) menyatakan bahwa dalam pembelajaran berbasis proyek, masalah didefenisikan dengan tantangan yang dapat diselesaikan dengan desain proyek, tahapan proyek yang berjenjang. Dengan kata lain masalah dalam model pembelajaran berbasis proyek yang adalah tujuan diadakannya proyek. Keuntungan dari pembelajaran berbasis proyek yaitu: (1) meningkatkan motivasi belajar siswa, (2) meningkatkan kemampuan pemecahan masalah, (3) meningkatkan kolaborasi, dan (4) meningkatkan keterampilan mengelola sumber yaitu bertanggung jawab untuk menyelesaikan tugas yang kompleks. (Thomas dalam Prabowo, A. 2012).

\section{B. Penerapan Model Pembelajaran Berbasis Proyek pada Materi Statistika \\ Sebagai salah satu contoh} Penerapan model pembelajaran berbasis proyek pada materi statistika kelas VIII dilaksanakan dalam empat kali pertemuan (10 jam pelajaran) dalam mencapai kompetensi inti (KI)-1, KI-2, KI-3 pada kompetensi dasar (KD)-3.10 menganalisis data berdasarkan distribusi data, nilai ratarata, median, modus, dan sebaran data untuk mengambil kesimpulan, membuat keputusan, dan membuat prediksi. Serta 
KI-4 pada KD-4.10 menyajikan dan menyelesaikan masalah yang berkaitan dengan distribusi data, nilai rata-rata, median, modus, dan sebaran data untuk mengambil kesimpulan, membuat keputusan, dan membuat prediksi.

Melalui proses pembelajaran materi statistika, siswa memiliki pengalaman belajar sebagai berikut:
a. Mengurutkan data tunggal menggunakan diagram batang-daun.
b. Menyajikan data dengan tabel distribusi frekuensi data tunggal dan data kelompok
c. Menghitung mean (rata-rata), modus, dan median serta menjelaskan maknanya.

d. Menghitung jangkauan data, quartil, dan jangkauan interkuartil data tunggal serta menjelaskan maknanya.

Untuk mencapai pengalaman belajar tersebut diperlukan 5 pertemuan dengan rincian sebagai berikut:

a. Pertemun 1 adalah membelajarkan siswa dengan sintak pembelajaran mengamati, mengumpulkan menanya, mengasosiasi, informasi, mengkomunikasikan terkait materi Menghitung mean (rata-rata), modus, dan median serta menjelaskan maknanya.

b. Pertemuan 2 adalah membelajarkan siswa dengan sintak pembelajaran mengamati, menanya, mengumpulkan informasi, mengasosiasi, dan mengkomunikasikan terkait materi Menghitung jangkauan data, quartil, dan jangkauan interkuartil data tunggal serta menjelaskan maknanya.

c. Pertemuan 3 adalah menerapkan model pembelajaran berbasis proyek dengan sintak Penentuan Pertanyaan Mendasar (Start With the Essential Question), Mendesain Perencanaan Proyek (Design a Plan for the Project), Menyusun Jadwal (Create a Schedule).

d. Pertemuan 4 adalah menerapkan model pembelajaran beerbasis proyek dengan sintaks Memonitor siswa dan kemajuan proyek (Monitor the Students and the Progress of the Project), Menguji Hasil (Assess the Outcome).

e. Pertemuan 5 adalah melakukan evaluasi terhadap pengalaman belajar.

Contoh desain/rencana penyelesaian tugas proyek dengan deskripsi kegiatan sebagai berikut:

1. Mengumpulkan informasi dari berbagai sumber.

2. Mencari atau mengamati atau menyelidiki benda-benda yang ada di sekitar untuk dijadikan data.

3. Menulis catatan serta mengelompokan data yang diperoleh.

4. Komunikasi dengan guru terkait dengan kegiatan yang sudah dilakukan. 
5. Membuat laporan dalam bentuk paparan atau presentasi.

6. Persiapan presentasi/ pengecekan perlengkapan.

7. Pelaksanaan presentasi

8. Mencatat komentar dan saran dari teman-teman dan guru.

Contoh lembar kerja proyek dalam materi statistika:

a. Menentukan rata-rata berat badan.

Terlebih dahulu siswa membuat kelompok 5-6 orang siswa. Selanjutnya setiap kelompok melakukan kegiatan pengukuran dan perhitungan data sebagai berikut:

1) Setiap anggota kelompok dan ketua kelomppok menimbang berat badannya masing-masing di ruang usaha kesehatan sekolah (UKS). Masing-masing pengukuran dilakukan dua kali agar lebih akurat.

2) Salah seorang anggota setiap kelompok mencatat hasil pengukuran tersebut.

3) Setiap kelompok berdiskusi untuk menentukan nilai ratarata hitung (mean) berat badan siswa pada kelompoknya.
4) Setiap kelompok mempresentasikan hasil diskusinya di depan kelas.

b. Menentukan nilai modus dan median dengan mengumpulkan data.

Terlebih dahulu siswa dikelompokkan ke dalam 4 kelompok. Selanjutnya setiap kelompok melakukan kegiatan pengumpulan data sebagai berikut:
1) Ketua kelomppok mengumpulkan data tentang nomor sepatu yang dipakai anggotanya, sekretaris mencatat data tersebut.

2) Setiap kelompok berdiskusi bagaimana cara yang praktis untuk menentukan modus dari data nomor sepatu siswa tersebut?

3) Setiap kelompok mempresentasikan hasil diskusinya di depan kelas.

\section{Penutup}

Untuk memperkuat pendekatan ilmiah (scientific), tematik terpadu (tematik antar mata pelajaran), dan tematik (dalam suatu mata pelajaran) perlu diterapkan pembelajaran berbasis penyingkapan/penelitian

(discovery/inquiry learning). Agar peserta didik menghasilkan karya kontekstual baik individual maupun kelompok maka sangat disarankan menggunakan pendekatan pembelajaran yang menghasilkan karya berbasis proyek(project based learning). Demikian pula pada Permendikbud Nomor 66 tahun 2013 tentang standar penilaian mengatakan bahwa seorang pendidik untuk menilai kompetensi keterampilan melalui penilaian kinerja yaitu penilaian yang menuntut siswa mendemonstrasikan suatu kompetensi tertentu dengan menggunakan tes praktik, proyek dan penilaian portofolio. Untuk penilaian proyek yang dilakukan oleh seorang pendidik, menurut Standar penilaian 
adalah dilakukan setiap akhir bab atau tema pelajaran.

Pembelajaran berbasis proyek adalah model pembelajaran yang memberikan kesempatan kepada guru untuk mengelola pembelajaran di kelas dengan melibatkan kerja proyek. Kerja proyek memuat tugastugas yang kompleks berdasarkan permasalahan (problem) yang sangat menantang, dan menuntut siswa untuk melakukan kegiatan merancang, memecahkan masalah, membuat keputusan, melakukan kegiatan investigasi, serta memberikan kesempatan siswa untuk bekerja secara mandiri maupun kelompok. Hasil akhir dari kerja proyek tersebut adalah suatu produk yang antara lain berupa laporan tertulis, presentasi atau rekomendasi.

\section{Daftar Pustaka}

Baker, E. et all. (2011). Project-based Learning Model, Relevant Learning for the 21st Century. Canberra: Pacific Education Institute at www.pacificeducationinstitute.org.

Hafiyusholeh, M. (2015). Literasi Statistik dan Urgensinya bagi Siswa. WAHANA, 64(1), 11-8.

Kemdikbud. (2013). Materi Pelatihan Guru Implementasi Kurikulum 2013, BPSDMPK dan PMP. Jakarta.

Maryati, I., \& Priatna, N. (2018). Analisis Kemampuan Literasi Statistis Siswa Madrasah Tsanawiyah dalam Materi Statistika. Journal Of Medives: Journal Of Mathematics Education IKIP Veteran Semarang. 2(2), 205-212.
Maryati, I. \& Priatna, N. (2018). Analysis of statistical misconception in terms of statistical reasoning. 4th International Seminar of Mathematics, Science and Computer Science Education IOP Publishing IOP Conf. Series: Journal of Physics: Conf. Series 1013 (2018) 012206 doi 10.1088/1742.6596/1013/1/012206.

Prabawati, M. N. (2018). Analisis Kemampuan Literasi Matematik mahasiswa Calon Guru Matematika. Mosharafa: Jurnal Pendidikan Matematika, 7(1), 113-120.

Prabowo, A. (2012). Pembelajaran Berbasis Proyek Untuk Meningkatkan Pemahaman Mahasiswa atas Permasalahan Statistika pada Perkuliahan Studi Kasus dan Penelitian. JURNAL KREANO, ISSN : 2086-2334 Diterbitkan oleh Jurusan Matematika FMIPA UNNES.

The Partnership for 21st Century Skills. (2008). 21st century skills, education, \& competitiveness.

Widyantini, T. (2014). Penerapan Model Project Based Learning (Model Pembelajaran Berbasis Proyek) dalam Materi Pola Bilangan Kelas VII Pusat Pengembangan dan Pemberdayaan Pendidik dan Tenaga Kerpendidikan (P4TK) Matematika. Pp. 1-19.

\section{Riwayat Hidup PenUlis} lyam Maryati, S.Pd. M.Pd.

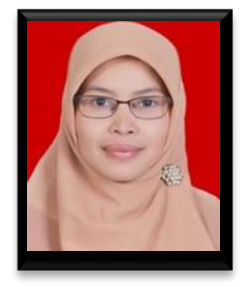

Staf pengajar di Institut Pendidikan Indonesia, Garut. Studi S2 Pendidikan Matematika Universitas Pasundan, Bandung; dan S3 Pendidikan Matematika Universitas Pendidikan Indonesia, Bandung, sampai dengan sekarang. 
This page is intentionally left blank 